\title{
RELATION BETWEEN CHARACTERISTICS OF WORK CLIMATE AND JOB EMPOWERMENT AT MANSOURA UNIVERSITY HOSPITAL
}

\author{
Zahia Ahmed Abo Elfotoh',Wafaa Fathi Sleem ${ }^{2}$, Hind Abdullah Mohamed ${ }^{3}$ \\ Bachelor Nursing Science, Faculty of Nursing-Benha University ${ }^{1}$, Assistant Prof of \\ Nursing Administration, Faculty of Nursing-Mansoura University ${ }^{2}$, Lecture of Nursing \\ Administration, Faculty of Nursing-Port-Said University ${ }^{3}$
}

\begin{abstract}
Background: Characteristics of work climate and job empowerment has a great impact on staff performance. Therefore, creating and examining a positive work climate that directly influences staff nurses' moral, behavior and attitude is main concern for health care providers Aim: The study aimed to investigate the relation between characteristics of work climate and job empowerment at Mansoura University Hospital. Sbjects and method: design: A descriptive correlational study was utilized. Setting: this study conducted in Mansoura University Hospital. Subjects: A sample of all staff nurses with total No (110) who were working in Mansoura University Hospital. Tool: Nurses' perception of work climate characteristics questionnaire and empowerment questionnaire. Results: Revealed that more than half of nurses had high work climate perception. Most work climate perception of staff nurses pertained to customer service, followed by quality, work facilitation and Communication. Also, the most staff nurses were empowered, and the highest mean score was for opportunities, meanwhile the lowest mean score for resources.. Conclusion: there was a highly statistically significant correlation between characteristics of work climate and job empowerment. Recommendations: Nursing leaders and hospital managers should provide a work climate that allows nurses to share ideas, team spirit and creativity. Furthermore, highlight the importance of empowerment strategies that allow nurses to work in a healthy working environment.
\end{abstract}

Keywords: Characteristics of work climate, Empowerment, Staff nurses. 


\section{INTRODUCTION}

The organizational work climate and job empowerment is considered as a vital component that is essential for the progress of the organization, the organizational climate is a key to corporate success which determines the actions and behaviors of workers. It comprises a set of attitudes, values and practices that characterize the members of a particular organization (Kassem \& Gaber, 2015). Organizational climate refers to the values, beliefs that are not visible but exist within the employee's behavior and action (Moghimi \& Subramaniam, 2013). Organizational climate is based on the premise that the overall health of an organization can be assessed by measuring individual employees' perceptions of their work environments (Giles, 2010).

Besides, organizational climate is formed of sharing values, beliefs and behavioral norms in an organization. So, the perceptions of employees about work environment, is based upon value system, prevalent conditions, factors affecting and events occurring at workplace (Ahmad, Ali, \& Ahmad, 2012). Kiefer, Kojetin \& Brannon (2005) mentioned several factors that contribute to a favorable climate and affect staff nurses performance including: empowerment, job design, organizational factors, nurseclient relationships, nurses- supervisor relationships and peer to peer relation (Zayan,et al., 2013).

Organizational climate may be more efficient, and, at the same time, may ensure best care practices, if the work environment is perceived more positive by staff nurses, it reflects such benfits as better performance, health team safety and satisfaction, organizational commitment, patient satisfaction and low rat of nurses turnover (Zayan, 2013).

Holloway (2012) reported, that , Litwin and Stringer (1968) categorized organizational climate into the following eight typical variables; organizational structure, standards, responsibility, support, commitment, reward, warmth, risk and conflict. Meanwhile, Martine (2006) categorized organizational climate into the following 10 dimensions: work facilitation, concern for people, team building, decision making, participation, communications, customer service, quality, staff/physician relationship and compensation (Awad, 2008).

Breau \& Rheaume (2014) suggest strategies that used in promoting workplace empowerment have the potential to improve nurses work environment.Several factors 
that contribute to a favorable climate and affect staff nurses performance including: empowerment, job design, organizational factors, nurse- client relationships, nursessupervisor relatioships and peer to peer relation (Zayan et al., 2013).

Workplace empowerment is defined as the having the power to access the structural factors within the work environment that enable the employee to get work done (Purdy, Laschinger, Finegan, Kerr \& Olivera, 2010). Empowerment is the process that facilitate the participation of others in decision making and taking action within an environment where there is equitable distribution of power (Wise, 2014).

Nursing supervisors empower their staff when they equip them to function on their own, without direct oversight and constant supervision. Empowering others require supervisors to give their people opportunities to contribute knowledge and expertise and to encourage them to take new tasks and to improve their capabilities (Greer \& Plunkett, 2007). According to McConnell (2014) empowerment has many benefits, it enhances the feeling of self- efficacy and self- confidence, reduces the feeling of helplessness, enhance the feeling of control over work, and enthusiastic the staff.

McConnell (2014) classified empowerment in to external and internal. External empowerment gives people the authority to do what they are capable of handling. It encourages people to make judgments, reach decisions and then act. It liberates workers from oversight and direction while internal empowerment or self-empowerment is what individuals generate intrinsically, like they generate enthusiasm or optimism and it reflects competence, assertiveness, character, personality and charisma. Also, Laschinger, Finegan, Shamian, \& Wilk (2001) delineated empowerment into two connected variables; structural and psychological empowerment.

According to Kanter's theory of structural empowerment, power sources for employees arise from both formal and informal sources, formal power is achieved from the characteristics of the specific role one fills and informally through personal alliances and connections within the work. These forms of power increase the employees access to conditions that enable them to accomplish their work effectively. Empowering conditions include access to opportunities, information, support and resources (Purdy, Laschinger, Finegan , Kerrm. \& Olivera. 2010). 


\section{AIM OF STUDY:}

The aim of this study is to investigate the relation between characteristics of work climate and job empowerment through:-

1- Assessing characteristics of work climate at Mansoura University Hospital.

2- Determining job empowerment level among staff nurses at Mansoura University Hospital.

3- Finding out the relation between characteristics of work climate and job empowerment among staff nurses at Mansoura University Hospital.

\section{SUBJECTS AND METHOD:}

Research design: A descriptive correlational research design was used for the current study.

Study setting: The study was carried out at Mansoura University Hospital in all general medical units (three units with bed capacity 67 beds) and all general surgical units (five units with bed capacity 108 beds). Mansoura University Hospital provides a wide spectrum of health services at Delta region with total bed capacity 1800 beds.

Subjects: The subjects of this study included all staff nurses who were working in the previous units. They were seventy-five (75) staff nurses in general surgical units. Where, thirty five "35" staff nurses working in all general medical units.

\section{Tool for data collection:}

The tool was used to collect data for this study as the following:

Tool I: Nurses' perception of work climate characteristics questionnaire:

Part1: Personal and Job Characteristics of the study subjects. It comprises: age, gender, marital status, clinical unit, educational level, and years of experience..

Part2: Self-instructions Questionnaire to assess the nurses' perception of work climate characteristics, and it consist of thirty statements which grouped in ten dimensions: work facilitation (3statment), concern for nurses (3statement), team building (3statement), decision making (3statement), participation (3statement), communications (3statement), customer service (3statement), quality (3statement), staff/physician relationships (3statement) and compensation (3statement). 


\section{Scoring system:}

Work climate items were scored 1, 2, 3, 4 and 5 for the responses never, rarely, sometimes, often, and always, respectively. For each domain, the scores of the items were summed-up and the total divided by the number of the items, giving a mean score for the part. These scores were converted into a percent score, and means and standard deviations were computed. The work climate perception was considered to be high if the percent score was $60 \%$ or more, and low if less than $60 \%$. Based on cut of point $60 \%$.

Tool II: Empowerment questionnaire to assess the staff nurse empowerment level. It consists of 44 items with four domains as the following; opportunities (19 items), access to information (10 items), support (8 items) and resources (7 items).

\section{Scoring System:}

Empowerment items were scored 1, 2, 3, 4 and 5 for the responses never, rarely, sometimes, often, and always, respectively. For each domain, the scores of the items were summed-up and the total divided by the number of the items, giving a mean score for the part. These scores were converted into a percent score, and means and standard deviations were computed. The empowerment level was considered to be high if the percent score was $60 \%$ or more, and low if less than $60 \%$ (El-gazar 2014).

\section{Content Validity:}

A pilot study was carried out on $10 \%$ of the sample in the study setting that were included in the study sample. The purposes of the pilot study were to test the applicability and, feasibility and clarity of the study tools and it served to estimate the time needed to complete the tools. It also helped to find out any obstacles and problems that might interfere with data collection.

\section{Reliability:}

The reliability was assured by calculating the test of Cronbach's $\alpha$ co-efficient. Its value was (0.85), two tools 


\section{Ethical consideration:}

Before conduction of the study, an official letter was taken from the Dean of the Faculty of Nursing in Port Said University to the Director of Mansoura University Hospital. After an explanation of the purpose of the study, a written permission was secured. On data collection, a verbal agreement was taken from every nurses, after a clear and simple explanation of the purpose of the study. Also the researcher assured the respondents about anonymity of their answers, and that the information will be used for scientific research only and will be treated as confidential.

\section{Field work:}

The data were collected (5) days/week during the morning shift. The work was done between 12:00 pm to 2:00 pm. The researcher was present all the time to clarify any ambiguities and any questions. The field work lasted for four months throughout the period from beginning of May 2016 to the end of August 2016.

\section{Statistical analysis:}

Data were analyzed with SPSS version 22. The normality of data was first tested with one-sample Kolmogorov-Smirnov test. Qualitative data were described using number and percent. Continuous variables were presented as mean \pm SD (standard deviation) for parametric data.

\section{RESULTS:}

Table (1): indicates personal and job characteristics of study sample. As regard to age group, table shows that $46.4 \%$ of nurses were at age group 20: $<30$ years old. as regard to marital status, it was noticed that majority $(83.6 \%)$ of nurses were married. two-thirds of the staff nurses (68.2\%) are working in surgical unit and (31.8\%) are working in medical unit. $44.5 \%$ had nursing diploma, while less half of them $43.6 \%$ have less than 10 years of experience.

Table (2): shows total of work climate perception among staff nurses. According to the table, $55.5 \%$ of staff nurses had high work climate perception with the mean of (93.1 \pm 17.26$)$. The highest mean score of work climate perception was shown in customer service (12.15 \pm 2.39 ), followed by quality (10.02 \pm 3.03$)$, and then followed by work facilitation $(9.95 \pm 2.19)$, while the lowest percent of work climate perception showed in compensation $(5.65 \pm 3.1)$. 
Figure(1) : Evident that more than half staff nurses (55.5\%) had high work climate level, while $44.5 \%$ of them had low work climate perception.

Table (3), indicates that staff nurses who work in surgical unit have the highest mean score of work climate perception $(94.61 \pm 17.58)$. Also, this table shows that staff nurses who have experience 30 years or more and their age 50 years old or more have the highest mean score of work climate perception (101.75 \pm 13.12$)$. Regarding the educational level, it is obvious that staff nurses who have technical institute have the highest mean score of work climate perception $(94.05 \pm 19.46)$ followed by nursing with nursing diploma then nursing baccalaureate degree (94.02 \pm 17.36 and $89.75 \pm 13.25$ respectively). Nonetheless of these relations are statistically significant.

Table (4): According to this table, the majority of staff nurses were empowered with mean score $(146.24 \pm 25.03)$, the highest mean score of empowerment was shown in access to opportunities (67.91 \pm 12.04$)$, followed by access to information (31.29 \pm 7.54$)$, and then followed by access to support $(26.44 \pm 6.07)$, while the lowest mean score of empowerment showed in access to resources $(20.6 \pm 5.01)$.

Figure (2): According to this figure, the majority of staff nurses participated in the study $(72.7 \%)$ were empowered. While the lowest of them $(27.3 \%)$ not empowered.

As shown in table( 5): As table indicates, 52.7\% of empowered staff nurses are working in surgical unit. Concerning to age, the highest percentage of empowered staff nurses (31.8\%) at the age 20 to less than 30 years old. Also, this table reveals that $29 \%$ of empowered staff nurses have experience less than ten years. In relation to gender, $70 \%$ of empowered staff nurses are female. $34.5 \%$ of empowered staff nurses have nursing diploma. There was statistically significant relationship between age and years of experience with empowerment.

Table(6): display that there was highly positive statistically significant relationship between staff nurses work climate and job empowerment $(\mathrm{P}=<.001)$. 
Table (1): personal and job characteristics of the studied staff nurse $(n=110)$.

\begin{tabular}{|c|c|c|}
\hline Item & Number & Percent \\
\hline \multicolumn{3}{|l|}{ Age } \\
\hline $20:<30$ & 51 & $46.4 \%$ \\
\hline $30:<40$ & 41 & $37.3 \%$ \\
\hline $40:<50$ & 10 & $9.1 \%$ \\
\hline $50: 60$ & 8 & $7.3 \%$ \\
\hline Mean (SD) & \multicolumn{2}{|c|}{$31.26 \pm 8.36$} \\
\hline \multicolumn{3}{|l|}{ Gender } \\
\hline Male & 5 & $4.5 \%$ \\
\hline Female & 105 & $95.5 \%$ \\
\hline \multicolumn{3}{|l|}{ Marital Status } \\
\hline Single & 16 & $14.5 \%$ \\
\hline Married & 92 & $83.6 \%$ \\
\hline Divorced & 2 & $1.8 \%$ \\
\hline \multicolumn{3}{|l|}{ Clinical Unit } \\
\hline Medical & 35 & $31.8 \%$ \\
\hline Surgical & 75 & $68.2 \%$ \\
\hline \multicolumn{3}{|l|}{ Educational level } \\
\hline Nursing diploma & 49 & $44.5 \%$ \\
\hline Technical institute & 37 & $33.6 \%$ \\
\hline Faculty graduate & 24 & $21.7 \%$ \\
\hline \multicolumn{3}{|l|}{ Years of expe rience } \\
\hline Less than 10 & 48 & $43.6 \%$ \\
\hline $10:<20$ & 42 & $38.2 \%$ \\
\hline $20-<30$ & 12 & $10.9 \%$ \\
\hline $30-40$ & 8 & $7.3 \%$ \\
\hline Mean (SD) & \multicolumn{2}{|c|}{$11.77 \pm 8.9$} \\
\hline
\end{tabular}

Table (2): Mean score of work climate perception among staff nurses $(n=110)$.

\begin{tabular}{|l|c|c|}
\hline \multicolumn{1}{|c|}{ Work climate domains } & Min- max & Mean (SD) \\
\hline Work facilitation & $4-15$ & $9.95 \pm \mathbf{2 . 1 9}$ \\
\hline Concern for nurses & $3-15$ & $9.05 \pm 2.44$ \\
\hline Team building & $5-15$ & $7.71 \pm \mathbf{2 . 6}$ \\
\hline Decision making & $3-14$ & $7.67 \pm \mathbf{3 . 1 4}$ \\
\hline Participation & $3-15$ & $9.9 \pm \mathbf{2 . 1 3}$ \\
\hline Communication & $4-14$ & $9.75 \pm \mathbf{2 . 3 4}$ \\
\hline Customer service & $4-15$ & $12.15 \pm \mathbf{2 . 3 9}$ \\
\hline Quality & $3-15$ & $10.02 \pm \mathbf{3 . 0 3}$ \\
\hline Staff/physician relationships & $3-15$ & $9.25 \pm \mathbf{3 . 0 1}$ \\
\hline Compensation & $3-14$ & $5.65 \pm \mathbf{3 . 1}$ \\
\hline \multicolumn{1}{|c|}{ Total work climate } & $\mathbf{5 3 - 1 3 4}$ & $\mathbf{9 3 . 1} \pm \mathbf{1 7 . 2 6}$ \\
\hline
\end{tabular}




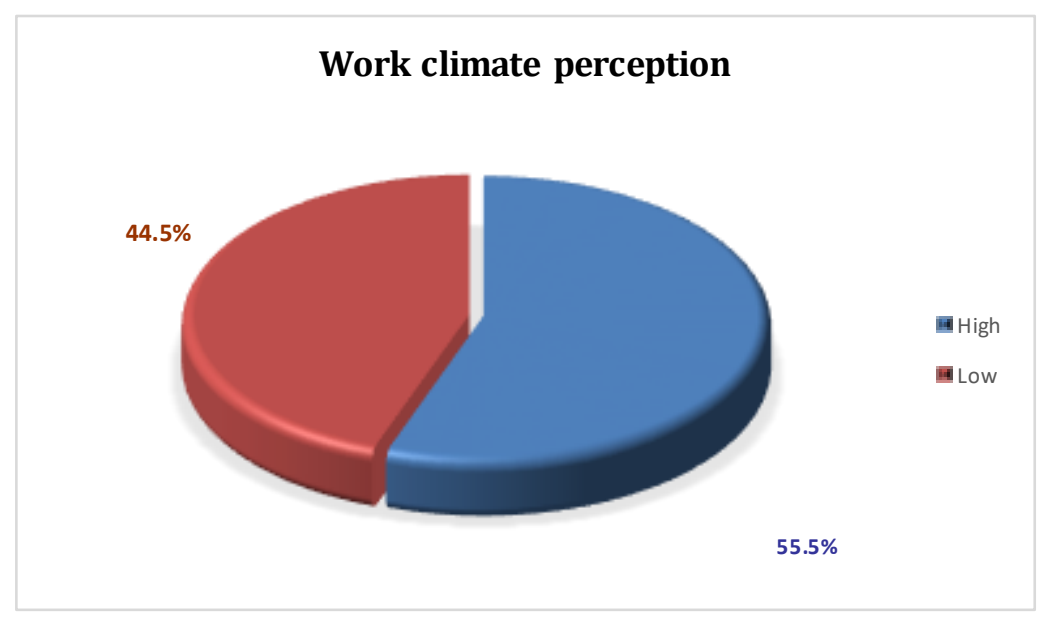

Figure (1): Total work climate perception as perceived by staff nurses $(n=110)$.

Table (3): Relation between staff-nurses' mean score of work climate perception and their personal and job characteristics $(\mathrm{N}=110)$.

\begin{tabular}{|c|c|c|c|}
\hline \multirow{2}{*}{ Item } & \multicolumn{3}{|c|}{ perception of work climate } \\
\hline & Mean $\pm \mathrm{SD}$ & Test of sig. & P. Value \\
\hline \multicolumn{4}{|l|}{ Gender } \\
\hline Male & $105.8 \pm 16.96$ & \multirow[t]{2}{*}{$t=1.699$} & \multirow[t]{2}{*}{.092} \\
\hline Female & $92.5 \pm 17.12$ & & \\
\hline \multicolumn{4}{|l|}{ Age } \\
\hline $20:<30$ & $95.12 \pm 15.28$ & \multirow{4}{*}{$\mathrm{F}=2.375$} & \multirow{4}{*}{.072} \\
\hline $30:<40$ & $87.95 \pm 19.57$ & & \\
\hline $40:<50$ & $97 \pm 15.72$ & & \\
\hline $50: 60$ & $101.75 \pm 13.12$ & & \\
\hline \multicolumn{4}{|l|}{ Marital Status } \\
\hline Single & $96.57 \pm 18.01$ & \multirow{3}{*}{$\mathrm{F}=2.690$} & \multirow{3}{*}{.072} \\
\hline Married & $93.07 \pm 16.79$ & & \\
\hline Divorced & $67 \pm 19.8$ & & \\
\hline \multicolumn{4}{|l|}{ Clinical Unit } \\
\hline Medical & $89.86 \pm 16.33$ & \multirow[t]{2}{*}{$\mathrm{t}=1.351$} & \multirow[t]{2}{*}{.179} \\
\hline Surgical & $94.61 \pm 17.58$ & & \\
\hline \multicolumn{4}{|l|}{ Educational level } \\
\hline Nursing diploma & $94.02 \pm 17.36$ & \multirow{3}{*}{$\mathrm{F}=.574$} & \multirow{3}{*}{.565} \\
\hline Technical institute & $94.05 \pm 19.46$ & & \\
\hline Baccalaureate degree & $89.75 \pm 13.25$ & & \\
\hline \multicolumn{4}{|l|}{ Years of experience } \\
\hline Less than 10 & $94.31 \pm 16.07$ & \multirow{4}{*}{$\mathrm{F}=1.288$} & \multirow{4}{*}{.282} \\
\hline $10:<20$ & $89.79 \pm 18.57$ & & \\
\hline $20-<30$ & $94.08 \pm 18.68$ & & \\
\hline $30-40$ & $101.75 \pm 13.12$ & & \\
\hline
\end{tabular}

$\mathrm{t}=$ Independent $\mathrm{t}$ test

$\mathrm{F}=$ ANOVA test 
Table (4): Mean score of empowerment among the staff nurses $(n=110)$.

\begin{tabular}{|l|c|c|}
\hline \multicolumn{1}{|c|}{ Empowerment Items } & Min - max & Mean (SD) \\
\hline Access to opportunities & $37-96$ & $67.91 \pm 12.04$ \\
\hline Access to information & $12-46$ & $31.29 \pm 7.54$ \\
\hline Access to support & $10-40$ & $26.44 \pm 6.07$ \\
\hline Access to resources & $10-31$ & $20.6 \pm 5.01$ \\
\hline Total empowerment & $\mathbf{8 2 - 1 9 3}$ & $\mathbf{1 4 6 . 2 4 \pm 2 5 . 0 3}$ \\
\hline
\end{tabular}

Empowerment levels as perceived by staff nurses

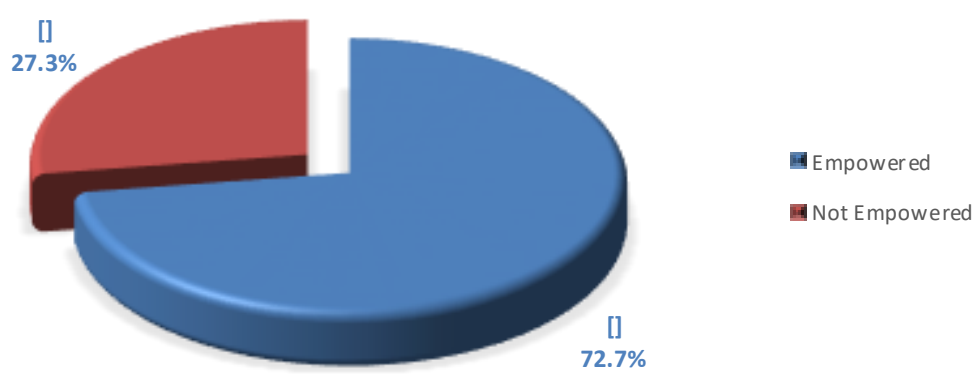

Figure (2): Empowerment levels as perceived by staff nurses $(n=110)$. 
Table (5): Relation between staff nurses' empowerment levels and their personal characteristics $(\mathrm{N}=110)$.

\begin{tabular}{|c|c|c|c|c|c|c|}
\hline \multirow{2}{*}{ Item } & \multicolumn{2}{|c|}{ Not Empowered } & \multicolumn{2}{|c|}{ Empowered } & \multicolumn{2}{|c|}{ Test of sig. } \\
\hline & No & $\%$ & No & $\%$ & $\mathbf{X}^{2}$ & $\mathbf{P}$ \\
\hline \multicolumn{7}{|l|}{ Gender } \\
\hline Male & 2 & 1.8 & 3 & 2.7 & \multirow{2}{*}{.428} & \multirow{2}{*}{.612} \\
\hline Female & 28 & 25.5 & 77 & 70 & & \\
\hline \multicolumn{7}{|l|}{ Age } \\
\hline $20:<30$ & 16 & 14.6 & 35 & 31.8 & \multirow{4}{*}{8.159} & \multirow{4}{*}{$.043^{*}$} \\
\hline $30:<40$ & 14 & 12.7 & 27 & 24.5 & & \\
\hline $40:<50$ & 0 & 0 & 10 & 9.1 & & \\
\hline $50: 60$ & 0 & 0 & 8 & 7.3 & & \\
\hline \multicolumn{7}{|l|}{ Marital Status } \\
\hline Single & 6 & 5.5 & 10 & 9.1 & \multirow{3}{*}{1.604} & \multirow{3}{*}{.448} \\
\hline Married & 23 & 20.9 & 69 & 62.7 & & \\
\hline Divorced & 1 & 0.9 & 1 & 0.9 & & \\
\hline \multicolumn{7}{|l|}{ Clinical Unit } \\
\hline Medical & 13 & 11.8 & 22 & 20 & \multirow[t]{2}{*}{2.521} & \multirow[t]{2}{*}{.167} \\
\hline Surgical & 17 & 15.5 & 58 & 52.7 & & \\
\hline \multicolumn{7}{|l|}{ Educational level } \\
\hline Nursing diploma & 11 & 10 & 38 & 34.5 & \multirow{3}{*}{1.790} & \multirow{3}{*}{.409} \\
\hline Technical institute & 13 & 11.8 & 24 & 21.8 & & \\
\hline Faculty graduate & 6 & 5.5 & 18 & 16.4 & & \\
\hline \multicolumn{7}{|l|}{ Years of experience } \\
\hline Less than 10 & 16 & 14.6 & 32 & 29 & \multirow{4}{*}{9.167} & \multirow{4}{*}{$.027 *$} \\
\hline $10:<20$ & 14 & 12.7 & 28 & 25.5 & & \\
\hline $20-<30$ & 0 & 0 & 12 & 10.9 & & \\
\hline $30-40$ & 0 & 0 & 8 & 7.3 & & \\
\hline
\end{tabular}

$\mathrm{X}^{2}=$ Chi-Square test

$*=$ Fisher's Exact Test

Table (6): Correlation between staff nurses work climate perception and job empowerment $(\mathrm{n}=110)$.

\begin{tabular}{|l|c|c|}
\hline \multirow{2}{*}{} & \multicolumn{2}{|c|}{ Job empowerment } \\
\cline { 2 - 3 } & r & P- Value \\
\hline Work climate perception & .478 & $<.001^{*}$ \\
\hline
\end{tabular}

\footnotetext{
* Significant at level of $5 \%$.

$\mathrm{r}=$ Pearson Correlation
} 


\section{DISCUSSION:}

In a competitive global setting, achieving organizational effectiveness and organizational survival is based on employee's attitudes and behaviors. For this reason, organizational climate has gained importance in organizational behavior researches. In particular, researchers have found links with organizational climate and employee performance, organizational effectiveness, productivity, job satisfaction, organizational commitment, organizational justice, work motivation, organizational alienation and empowerment (Heyart, 2011; Ahmad, Ali \& Ahmad 2012; Rahimic, 2013).

In this respect, the present study was conducted to investigate the relation between characteristics of work climate and job empowerment among staff nurses at Mansoura University Hospital through; assessing characteristics of work climate; determining the empowerment level of staff nurses; and finding out the relation between characteristics of work climate and job empowerment among staff nurses.

Regarding staff nurses' organizational climate perception, the findings of the present study revealed that more than half of the participating staff nurses at Mansoura University Hospital perceived a high level of organizational climate, whereas, the rest of them perceived the organizational climate as approximately low. This finding may be due to the nature of their work environment as availability of hospital financial resources, adequate work facilitates, good communication pointing to the presence of good spirits, good relationships and humane treatment among staff. Also, one explanation of this could be the familiarity with the work area at Mansoura University Hospital which allows greater control over the work environment.

The study result is consistent with, Aiken, Sloane, Bruyneel, Van DenHeede, and Sermeus (2013) who studying the work environment of nurses from 12 European countries and found that the highest percent of nurses had positive perception toward work climate. Also, Kassem and Gaber (2015) who concluded that, nurses perceived their organizational climate positively.

This result is inconsistent with that of Abd El-Megeed and Ahmed (1996) who found in their study of the organizational climate at critical and intensive care units at ElManial University hospitals that staff nurses perceived the climate as an open one, it is worth mentioning that Abd El-Megeed and Ahmed categorized organizational climate as open, controlled or closed. Unlike to this perspective, El-Salam, Ibrahim, Mohsen \& Hassanein. (2008) claimed that the majority of staff nurses in different units perceived 
moderate organizational climate. On other hand, numerous studies have indicated that nurses are dissatisfied with their work environment (Van Bogaert, Clarke, Willems \& Mondelaers, 2013).

Regarding to nursing staff empowerment', the findings of the present study revealed that the majority of staff nurses were empowered. These findings were congruent with that of Stewart, McNulty, Griffin \& Fitzpatrick (2010) in their study about empowerment among nurse practitioners which concluded that staff nurses had a high level of empowerment. Furthermore, Istomina et al. (2011) who conduct a study to assess empowerment among surgical staff nurses in seven Lithuania hospitals and found staff nurses were empowered with high level and there was a high presence of promoting empowerment factors and impeding factors were low. This is the same view of Brody, Barnes, Ruble\& Sakowski (2012) showed that the most common theme from interviews with all staff nurses was empowerment.

Also, EL-Gazar (2014) assess empowerment of staff nurses concluded that staff nurses had a high level of empowerment, in comparison with Fitzpatrick, Campo \& Lavandero (2011); Hauck, Griffin \& Fitzpatrick (2011); Bish, Kenny \& Nay (2012) their result reported that staff nurses were moderately empowered. Whereas, Aly (2007) reported that less than one third of staff nurses had job empowerment. Also, Abdou (2011) stated that nurses have low level of job empowerment.

As regards relation between personal and job characteristics and empowerment level of nurses. The result revealed statistically significant difference between empowerment level and personal and job characteristics in term of age and years of experience. This result illustrated that younger nurses are more empowered than older nurses. This may be due to younger nurses were likely to assert their power within the consultation compared to older nurses.

This is the same view of Ning, Zhong, Libo \& Qiejie (2009) who studied empowerment among Harbin, China hospitals and clarified that empowerment was perceived when nurses were younger. Moreover, Davies, Wong \& Laschinger, (2011) prove that an increase in age was associated with lower reported empowerment. This is in contrast with Zurmehly et al. (2009) who reported that Ohio state nurses between 50 and 60 years old had higher levels of empowerment. 
Concerning staff nurses' years of experience, the finding revealed that staff nurses who spend less than ten years were more empowered than nurses who spend more time in woke. This may be due to nurses who spend more time in woke become more exhausted and burnout. While nurses who spend less time were still willing and had power to share. This finding consistent with EL-Gazar (2014) who reported that staff nurses who spend less than ten years were more empowered than nurses who spend more time in woke. In contrast, Mcdermott et al., (1996) and Aly (2007) clarified that nurses who have more experience in their units have more opportunities to obtain regouition and rewards and use their knowledge and skills and became empowered.

Regarding educational qualification, the study findings founded that more empowered staff nurses have nursing diploma. our finding is congruent with EL-Gazar (2014) who claimed that more empowered staff nurses have nursing diploma. These findings were in contradiction with Istomina, Suominen, Razbadauskas, Martinkenas, Kuokkanen, \& Leino-Kilpi (2011), who assessed nurses' empowerment and found that nurses with higher education felt more empowered at their work.

Generally, findings of the present study clarified that there is an extremely high statistically significant relationship between staff nurses' work climate perception and staff-nurses' empowerment. This finding was in accordance with El-Salam et al (2008) who stated that There was a statistically significant positive correlation between organizational climate and nurses' empowerment.. Also, this finding goes in the same line with those of, Mok and Au-Yeung (2002) who stated that there was a positive correlation between organizational climate and psychological empowerment. In the same context, this result is also congruent with that of Breau\& Rheaume (2014) ICU nurses who have greater access to empowerment structures perceive their work environment as being healthier. These results corroborate other research linking empowerment to positive work environments (Laschinger, 2008; Manojlovich \& DeCicco, 2007; Purdy et al., 2010).

\section{CONCLUSION:}

\section{Based on study findings, it can be concluded that:}

In the light of the present study findings, it was concluded that, more than half of nurses had high work climate perception. Most work climate perception of staff nurses pertained to customer service, followed by quality, work facilitation and Communication. Also, most of staff nurses were empowered, and the highest mean score was for 
opportunities, meanwhile the lowest mean score for resources. Finally, there was highly positive statistically significant relation between Characteristics of work climate and job empowerment among staff nurses at Mansoura University Hospital.

\section{RECOMMENDATIONS:}

Based on the results of the present study, the following recommendations were suggested: Improve characteristics of work climate through:

- Develop training programs and motivate staff nurses to share in it.

- Energize nursing staff to increase their level of nursing education to increase their level of autonomy.

- Encourage staff nurses to learn new skills and to be up to date.

- Encourage staff nurses' ideas about upcoming department plans and get their advice when things go wrong.

- Enhance the staff nurses' communication skills through explain what's, haw and important of communication.

- Communicate hospital vision, mission, policies and rules for nursing staff.

- Appreciate and recognize when things go well and searching for ways to reward good work.

- Encourage nurses to participate and work as a team.

\section{Enhance staff nurses' empowerment through:}

- Provide nursing staff with work facilities such as equipment and supplies as possible to facilitate their empowerment process.

- Motive staff nurses and give them needed support to share in decision and solving problems.

- Make organizational information and knowledge available for all nursing staff.

- Identify empowerment barriers in the work environment and create empowerment strategy. 


\section{REFERENCES:}

Abd El-shafy. (2013). Relation between organizational climate and staff nurses job outcome. Unpublished Master thesis, Faculty of Nursing, Port Said University.

Abd El-Megeed M, Ahmed B. (1996). Relationship of organizational climate to quality of care among critical care nurses. Egyptian journal of international medicine, 5(1):97-112.

Abdou, S. (2011). Assess Stress and Empowerment among Nurses Interns during the Internships Year at Mansoura University Hospital. Unpublished Master thesis, Faculty of Nursing. Zagazig University.

Ahmad, Z., Ali, L. and Ahmad, N. (2012). Organizational climate: A study of pharmaceutical industry in Pakistan, African Journal of Business Management, 6(49): 11880-11886.

Aiken, L.H., Sloane, D.M., Bruyneel, L., Van Den Heede, K., \& Sermeus, W. (2013). Nurses' reports of working co+ditions and hospital quality of care in 12 countries in Europe. International Journal of Nursing Studies, 50, 143-153.

Aly, R. (2007). The relation between leadership of the head nurses, staff nurses' empowerment and job satisfaction. Unpublished Master Thesis, Faculty of Nursing, Suez Canal University.

Awad N., (2008). The relationship between nurses' perception of organizational work climate and their job empowerment. Unpublished Master thesis, University of Alexandria, Faculty of Nursing.

Bish, M., Kenny, A. \& Nay, R. (2012). Perceptions of structural empowerment: nurse leaders in rural health services. Journal of Nursing Management, 22(1), 29-37.

Breau, M., \& Rheaume, A. (2014). The relationship between empowerment and work environment on job satisfaction, intent to leave, and quality of care among ICU nurses. Dynamics, 25(3), 16-24. 
Brody, A.A., Barnes, K., Ruble, C. \& Sakowski, J. (2012). Evidence-based practice councils: potential path to staff nurse empowerment and leadership growth. US National Library of Medicine ;42(1):28-33.

Davies, A., Wong, C. A., \& Laschinger, H. K. (2011). Nurses' participation in personal knowledge transfer. The role of leader-member exchange (LMX) and structural empowerment. Journal of Nursing Management, 19(5), 5632-643. doi:10.1111/j.13652834.2011.01269.

EL-Gazar, H.E. (2014). Relationship Between Emotional Intelligence of Head Nurses and Empowerment of Staff nurses. Unpublish Thesis. Port Said University.

El-Salam, G.A. Ibrahim, M.M. Mohsen, M.M. and Hassanein S.E. (2008). Relationship between organizational climate and empowerment of nurses in Menoufiya hospitals, Egypt. Eastern Mediterranean Health Journal,. 14(1), 5.

Fitzpatrick, J.J, Campo, T.M., \& Lavandero, R. (2011). Critical care staff nurses: Empowerment, certification and intent to leave. Journal of the American Academy of nurse practitioners, 31(6), 12-17. Retrieved from: http://www.onlinelibrary.wiley.com.

Giles, P., (2010). The Impact of Adult Degree-Completion Programs on the Organizational Climate of Christian Colleges and Universities, Doctoral Thesis, Walden University.

Greer, C.R., \& Plunkett, W.R. (2007). Supervisory management ,11th ed.. New Jersey: Pearson Education Inc.

Heyart, B., (2011). The Role of Organizational Climate and Culture in Service Encounters Doctoral Thesis, Wayne State University.

Holloway, J.B. (2012). Leadership Behavior and Organizational Climate: An Empirical Study in a Non-profit Organization, Emerging Leadership Journeys, 5(1): 935.

Hauck, A., Quinn Griffin, M. T., Fitzpatrick, J. J. (2011). Structural empowerment and anticipated turnover among critical care nurses. Journal of Nursing Management, 19 (2), 269-276. 
Istomina, N., Suominen, T., Razbadauskas, A., Martinkenas, A., Kuokkanen, L., \& Leino-Kilpi, H. (2011). Lithuanian nurses' assessments of their empowerment. Scandinavian Journal of Caring Sciences, 26(1), 3- 11.

Kassem, A. H., \& Gaber, H. (2015). Organizational climate and its impact on nurse's job empowerment at Main Mansoura University Hospital and Urology and Nephrology Center. IOSR Journal of Nursing and Health Science (IOSRJNHS), 4(2), 4048.

Kiefer, K.M., Kojetin, L.H., Brannon, D.A. (2005). Guide to Selected Instruments to Examine Direct Care Worker Experiences and Outcomes, available at: http//asp.Hhs.gov/daltcp reports/ dcw.

Laschinger, H. K. S. (2008). Effect of empowerment on professional practice environments, work satisfaction, and patient care quality: Further testing the nursing worklife model. Journal of nursing care quality, 23(4), 322-330

Litwin, G. H., \& Stringer, R. A. (1968). Motivation and organizational climate. Boston: Division of Research, Graduate School of Business Administration, Harvard University.

Manojlovich, M., \& Laschinger, H. (2007). The nursing worklife model: Extending and refining a new theory. Journal of nursing management, 15(3), 256-263

McConnell, C. R. (2016). Umiker's management skills for the new health care supervisor, $6^{\text {th }}$ ed., . Jones \& Bartlett Learning

Martine P. (2006). Organizational climate survey. Available at: http://www.mhei.org/consult/ocs.

Ning, S., Zhong, H., Libo, W., \& Qiujie, L. (2009). The impact of nurse empowerment on job satisfaction. Journal of Advanced Nursing, 65(12), 2642-2648.

Laschinger, H. K. S., Finegan, J., Shamian, J., \& Wilk, P. (2001). Impact of structural and psychological empowerment on job strain in nursing work settings: expanding Kanter's model. JONA: The Journal of Nursing Administration, 31(5), 260272. 
Laschinger H.K.S. (2008). Effect of empowerment on professional practice environments, work satisfaction, and patient care quality: further testing of the Nursing Worklife Model. Journal of Nursing Care Quality 23 (4),322-330.

Moghimi, S., and Subramaniam, I.D., (2013). Employees' Creative Behavior: The Role of Organizational Climate in Malaysian SMEs, International Journal of Business and Management, 8(5): 1-13.

Mok E, Au-Yeung B. (2002). Relationship between organizational climate and empowerment of nurses in Hong Kong. Journal of nursing management, 10 (1):129-37.

McDermott, K., H.K.S. Laschinger and J. Shamian. (1996). "Work Empowerment and Organizational Commitment." Nursing Management 27(5): 44-48.

Purdy, N., SPENCE LASCHINGER, H. K., Finegan, J., Kerr, M., \& Olivera, F. (2010). Effects of work environments on nurse and patient outcomes. Journal of nursing management, 18(8), 901-913.

Rahimić, Z., (2013). Influence of Organizational Climate on Job Satisfaction in Bosnia and Herzegovina Companies, International Business Research, 6(3): 129-139.

Stewart, J.G, McNulty, R., Griffin, M.Q., \& Fitzpatrick, J. (2010). Psychological empowerment and structural empowerment among nurse practitioners. Journal of the American Academy of nurse practitioners, 22(1), 27-34.

Van Bogaert, P., Kowalski, C., \& Weeks, S. M. Van heusden, D., \& Clarke, SP (2013). The relationship between nurse practice environment, nurse work characteristics, burnout and job outcome and quality of nursing care: A cross-sectional survey. International Journal of Nursing Studies, 50(12), 1667-1677.

Wise, P.S.Y. (2014): Leading \&managing in nursing, 5th ed., USA: El-Sevier Mosby Inc.

Zayan, N.M., Reizian, A.E. and Hamouda, G. M. (2013). Relationship between Organizational Climate and Nurses' Outcomes. J Am Sci 2013;9(5):184-192]. (ISSN: 1545-1003. 
Zurmehly, J., Martin, P. A., \& Fitzpatrick, J. J. (2009). Registered nurse empowerment and intent to leave current position and/or profession. Journal of nursing management, 17(3), 383-391.

\section{العلاقة بين خصائص بيئة العمل و التمكين الوظيفى فى مستشفى المنصورة الجامعى زاهية احمد ابو الفتوح - أ.م .د/وفاء فتحى سليم - م/ هند عبد الله محمد}

بكالريوس تمريض _كلية التصريض _جامعة بنها ،/ستاذ مساعد ادرةة التصريض_كليه التصريض_جامعة المنصورة،

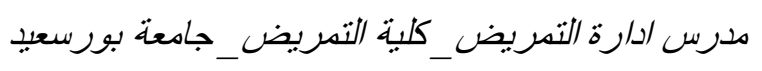

\section{الـــــلاصــة}

تؤثر خصائص بيئة العمل و التمكين الوظيفي على أداء الممرضـات. الـهدف مسن الـدراسـة: هدفت هذه الدراسة الي تحديد العلاقة بين خصائص بيئة العمل و التمكين الوظيفي لدي الهيئة التمريضية بمستشفى المنصورة

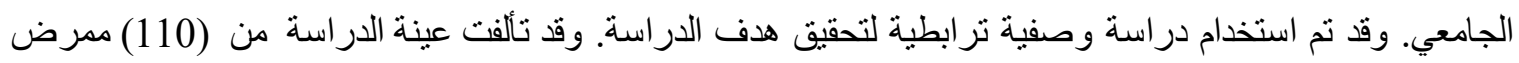

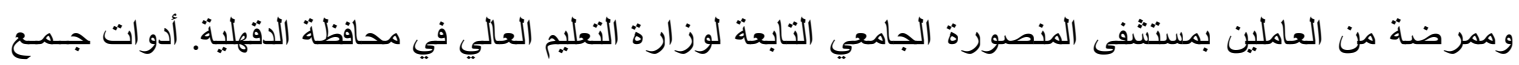

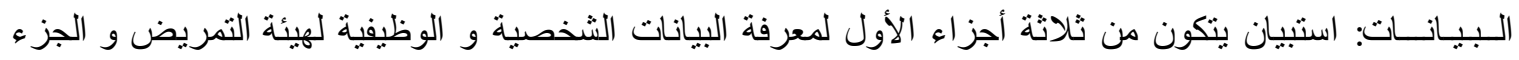

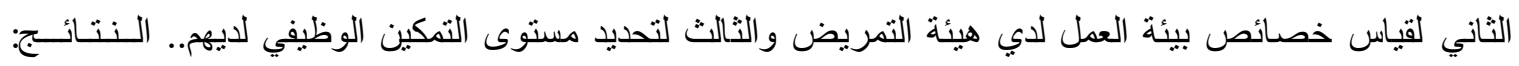

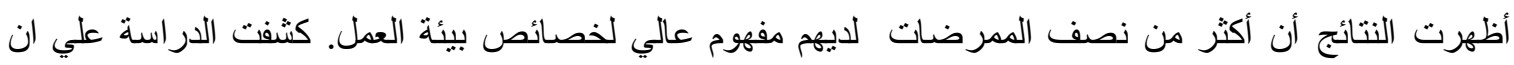
(72.7\%) من الممرضات لديهن تمكين وظيفي. الاسـتنتاجـات: وفقا للمشاركين توجد علاقة قويه بين خصائص بيئة العمل و التمكين الوظيفي لدي الممرضات. لنلك أوصت هذه الدراسة بتحسين خصائص بيئة العمل ، كما يجب أن يتم تعزيز التمكين الوظيفي لدى أعضاء هيئة التمريض من خلال تشجيعهم على المشاركة في اتخاذ القرار و إتاحة المزيد من المعلومات و الإمكانيات.

الكلمات المرشدة: خصائص بيئة العمل، التمكين ، الممرضات 